* (CAMPOS, Augusto de. Balanço da bossa e outras bossas. São Paulo: Perspectiva, 1974.)
Aproxima-se o momento de se fazer um balanço consistente dos estudos acadêmicos sobre a música popular brasileira, a sua relação com outras artes, em particular com a literatura e o cinema, e a importância na formação de nosso repertório cultural.

Dos primeiros estudos musicológicos empreendidos por Mário de Andrade nas décadas de 1920 e 1930 até as investigaçôes mais recentes, a trajetória da crítica concebida e exercida na universidade apresenta-se como um esforço de leitura da música popular focada na canção, nas chamadas "poéticas da palavra cantada".

Do hoje clássico Balanço da bossa e outras bossas de Augusto de Campos, ${ }^{*}$ lançado em 1968, passando pela contribuição de especialistas na área de Musicologia como Martha Ulhôa e Carlos Sandroni, sociólogos e antropólogos como Celso Favaretto, Roberto DaMatta, Elizabeth Travassos, Santuza Naves e Hermano Vianna e de críticos na área de Letras como Walnice Galvão, Heloísa Buarque de Hollanda, Affonso Romano de Sant'Anna, Silviano Santiago, Luiz Tatit, José Miguel Wisnik, Fred Góes, Claudia Neiva de Matos, entre outros, a crítica acadêmica ganhou força com a entrada em cena de grupos de pesquisa comprometidos com um projeto interdisciplinar de investigação.

Este texto é o produto parcial de um projeto de pesquisa que pretende mapear, historicizar e problematizar distintos exercícios etnográficos, no campo da Musicologia, da Etnomusicologia e da Crítica textual, de interpretação da formação da cultura brasileira e do lugar da música popular urbana na constituição de um imaginário identitário nacional.

Este ensaio é todo ele dedicado ao pensamento de Mário de Andrade. O autor de Pauliceia desvairada é muito mais conhecido pela sua poesia, prosa e vasta correspondência trocada ao longo de toda a vida com alguns dos mais representativos intelectuais e artistas brasileiros do que pelos seus textos críticos sobre literatura, artes plásticas, dança e música. Nosso objetivo é provocar aproxi- 
mações entre os seus diversos escritos, buscando, numa perspectiva intertextual, entender como Mário tentou aplicar a seus poemas, contos e romances uma prática escritural em nada distante de sua metodologia de etnógrafo. O texto ficcional, para a economia da nossa reflexão, é considerado um espaço de especulação crítica e de reflexão teórica.

Algumas observações iniciais visam localizar os ensaios escritos por Mário sobre a música em geral e especificamente a brasileira. A primeira diz respeito aos textos que, em sua grande parte, foram produzidos sob o signo da diacronia, uma tentativa historiográfica de compreensão da evolução das formas e gêneros musicais. A Pequena história da música (1929) segue esse modelo e pretende fazer uma leitura globalizante (da Antiguidade às experiências na época vanguardistas) da música ocidental. A segunda vertente textual musicológica diz respeito ao famoso Ensaio sobre a música brasileira, de 1928, e aos livros Aspectos da música brasileira (publicado a partir de artigos, conferências e ensaios escritos na década de 30) e Música, doce música (publicado em 1934). Ela problematiza questôes que compreendem a relação música erudita e formação social brasileira e as manifestações populares no universo rural e urbano. Uma terceira matriz abrange a descrição pormenorizada, acompanhada de notações musicais, de peças folclóricas, como em Música e feitiçaria no Brasil, publicada a partir de uma conferência proferida por Mário em 1933.

Não nos interessa neste estudo a leitura pormenorizada da música no Ocidente (subentende-se a erudita, naturalmente), nem a sua vertente no Brasil e muito menos a de acepção folclórica. Trabalhamos com índices propostos por cada uma delas como substrato de compreensão do fenômeno na atual fase da música popular urbana no Brasil. O conjunto de pressupostos teóricos e instrumentos analíticos empregado por Mário de Andrade e por diversos outros pensadores aqui citados será intertextualizado e estrategicamente utilizado em função de nosso objetivo principal - o entendimento da importância da música popular na sociedade brasileira como espaço de autorreflexão, sua força de configuração metacrítica no interior do debate das ideias e a sua condição atual de mercadoria prioritária da indústria cultural.

Este ensaio segue pelo tortuoso e delicado caminho de uma teoria crítica da MP urbana em tensão com distintos códigos culturais e estéticos. O pensamento de Mário, riquíssimo em suas pro- 
•(KERMAN, Joseph. Musicologia. São Paulo: Martins Fontes, 1987: 4-5.) vocações, nos parece o ponto de partida, o grau zero. Mas ele não se afigura suficiente para ler determinadas questões nem essa reflexão pretende se fechar nas ideias do pensador paulista.

Um dos mais férteis caminhos de investigação da música nas últimas décadas foi aberto, sem dúvida nenhuma, pela Etnomusicologia. Segundo Joseph Kerman:

A Etnomusicologia é popularmente entendida como o estudo da música não ocidental - ou músicas, como os próprios etnomusicólogos preferem dizer. Com efeito, eles possuem sua própria definição abrangente de Etnomusicologia, a famosa frase de Alan P. Merriam: $O$ estudo da música na cultura. Consideram seu domínio todo o universo da música - a música erudita ocidental, a música folclórica e popular ocidental, as músicas não-ocidentais simples e complexas; não foi por acaso que Seeger, o musicólogo sistemático, também foi o pai da Etnomusicologia moderna. No entanto, o que de fato ocupou de modo mais intenso os etnomusicólogos foram as músicas altamente desenvolvidas da Indonésia, Japão e Índia, e as músicas menos desenvolvidas dos ameríndios e africanos subsaarianos. Elas são estudadas a fim de se produzirem acuradas descrições técnicas, por um lado, e informação sobre o papel desempenhado pela música em suas respectivas sociedades, por outro.

Os estudos de Adler e Riemann já indicavam a presença de uma Musicologia comparada, voltada ao estudo, como afirma Kerman, da música como linguagem nas relações comunicativas e de seu valor simbólico nas sociedades. Essa Musicologia comparada incorpora contribuições de diferentes áreas, como a Antropologia, a Sociologia e a Etnografia, transformando-se numa disciplina academicamente reconhecida como Etnomusicologia.

As considerações de Kerman refletem de certo modo alguns impasses e equívocos que musicólogos e etnomusicólogos funcionalistas alimentaram sobre as suas respectivas atribuições e sobre os seus espaços de atuação. Definir Etnomusicologia como "o estudo da música na cultura”, como o faz Merriam, citado por Kerman, parece-nos por demais genérico e, ao mesmo tempo, ambíguo. Trata-se de reafirmar o estereótipo da pesquisa de campo como instrumento de observação por contraste das variantes culturais. Conceitos como "o pai da Etnomusicologia" (referindo-se a Seeger), "músicas altamente desenvolvidas" e "menos desenvolvidas" constroem um quadro de valores sedimentados na busca das origens, na configuração de uma investigação de caráter substancialista e no estabelecimento de estruturas representativas hierarquizadas. 
Apesar da constatação de dificuldades teóricas específicas, o advento da Etnomusicologia contribuiu decisivamente para a democratização e alargamento dos estudos musicológicos. Os escritos do americano Charles Seeger tornam-se referência obrigatória, suscitando polêmicas e iluminando algumas áreas nebulosas da formação crítica musicológica.

Em dois de seus mais importantes textos, Studies in Musicology e Semantic, Logical and Political Considerations Bearing upon Research in Ethnomusicology, podemos observar a defesa que Seeger faz da necessidade de reavaliaçóes e mudanças no campo da visão de Musicologia conservadora. Para ele, a leitura da música não poderia ser um mero exercício de reflexão analítica das técnicas de composição. O procedimento mais usual dos musicólogos era o de considerar a obra independente de seu contexto de produção, isolando-a como um objeto fechado em si, de definição e constituição autorreferentes. Dessa forma, pensa Seeger, a música não seria uma linguagem social, com todas as implicações comunicativas, e sim um objeto de caráter autônomo, que traria em sua própria estrutura a chave única de acesso a sua compreensão.

Se buscarmos analogia nos estudos literários modernos, veremos que a definição de música empregada pela Musicologia tradicional corresponderia à conceituação de literatura do New Criticism. No mesmo espaço de produção de ideias, os Estados Unidos dos anos 30, teóricos do texto musical e do texto literário buscavam na crítica de acepção formalista a abordagem intrínseca de seus respectivos objetos.

Contra uma leitura redutora da música que a considerava linguagem acabada, Seeger buscou compreender o fenômeno não só do erudito, mas também do folclórico e do popular, à luz de uma metodologia fincada no terreno da estética marxista, da sociologia e da antropologia cultural. Em seu Preface to a Critique of Music, ele afirma:

Graças à antropologia, a documentação contextual atingiu um alto nível de proficiência técnica no que se refere às músicas tribais. Ela é um pouco menos forte no domínio da música folclórica ocidental. Ainda é muito fraca no tratamento do idioma das elevadas, profissionais, belas artes da música. (É estranho que ainda nos falte um nome para esse idioma!) e é deploravelmente fraca no lidar com o contexto do idioma popular - mais um sem nome próprio.

Seeger aponta para uma tarefa inconclusa. Se a antropologia (cf. Lévi-Strauss - O cru e o cozido) destaca a música ao lado do
- (SEEGER, Charles. Studies in Musicology, 1935-1975. Los Angeles: University of California Press, 1977.) • (apud KERMAN. op. cit.:
234) 
mito como espaços privilegiados da análise (estrutural) das culturas, cabe à Etnomusicologia a construção teórica de modelos que compreendam a articulação texto/contexto desde a música erudita até a de definição popular. Esse idioma sem nome seria constituído pela sobremodalização de linguagens diversas sob a moldura de uma leitura ideologizante das distintas manifestações culturais.

Arriscamo-nos novamente a tentar construir uma ponte ligando as teorias da música às da literatura. A necessidade que a Etnomusicologia possuía de ler a produção musical a partir de variantes contextuais, particularmente as que póem em cena os agentes sociais e seus interesses de classe, corresponde, no campo das correntes críticas da literatura, a busca de compreensão do fenômeno literário sob as lentes dialéticas da análise sociológica. Transpõe-se da margem de interesse das marcas intrínsecas do objeto para o outro lado, o dos componentes extrínsecos como força interpretativa do estético.

As críticas de Seeger aos musicólogos conservadores, em especial ao seu etnocentrismo, acompanhadas por outro importante ensaísta, Allan Merriam, provocaram uma ruptura com as análises de base estilística, formalista e histórico-descritiva. Suas propostas de abordagem produziram um corte verticalizante na compreensão do objeto musical, direcionando a atenção para as pesquisas de formas e manifestações subvalorizadas pelo academicismo musicológico.

Sua investigação voltou-se para os países submetidos ao regime colonial, particularmente os das Américas, onde, segundo ele, pulsava uma extraordinária riqueza musical.

O surgimento da Etnomusicologia, aliada a outras disciplinas, contrapõe-se ao exercício musicológico conservador, articulando uma primeira tentativa interdisciplinar de compreensão da música. A historiografia voltada para a periodização diacrônica e para a apreciação biográfica dos compositores, acrescida da teoria musical e da pedagogia da composição, não representavam mais o único procedimento investigativo autorizado e reconhecido. A análise musical, centrada na compreensão exclusiva do significado da obra a partir de seus componentes intrínsecos, mostrava-se de igual maneira insuficiente.

O etnomusicólogo incorpora todos os elementos da Musicologia tradicional e a eles acrescenta a necessidade de estabelecimento de correlações de força antes não exercitadas. Não só o conhecimento dos elementos estruturais e funcionais da música, mas 
também o reconhecimento de sua importância social compõem o seu quadro de abordagem. A nova Musicologia, representada por Seeger, Sachs, Lang, Lowinsky e Tomlinson, dentre outros, pode ser compreendida como a de aproximação contextual.

De certa maneira, a trajetória de transformação da Musicologia positivista e funcionalista em campo da investigação histórica e sociológica nos ajuda a perceber a importância do pensamento de Mário de Andrade sobre a música e seus desdobramentos em outras atividades culturais. Sua formação musicológica aponta inicialmente para uma concepção conservadora de análise, como podemos verificar na Pequena história da música, mas o contato com novas ideias, absorvidas num momento de grandes mudanças, acabam por produzir uma alteração de rumo, fazendo de seus escritos testemunhos da ambiguidade e da contradição do processo de sistematização dos estudos musicológicos.

Identificamos um primeiro Mário, convencido da necessidade de preservação das formas "altas", "nobres", "bem-acabadas", da técnica apurada e do respeito à tradição erudita; professor de piano do Conservatório de Música de São Paulo, seduzido pela técnica dos grandes mestres; esteta apolíneo que sustenta o triunfo harmônico da tonalidade. Dissonante, polifônico, polirrítmico e atonal - o outro Mário é a busca incessante de ruptura, renovação formal, originalidade transgressora; que deseja a música como doce armamento de guerra, dioniso embriagado e engajado em polêmicas. Dois, vários Mários, esticando a corda que sustenta o arco e distende a lira.

Nossa estratégia de leitura da produção musicológica de Mário de Andrade aponta para a estreita aproximação proposta por ele entre música e poética, entre observação e produção, entre crítica e ficção. Não nos interessa estudar minuciosamente os textos descritivos sobre a história da música ocidental nem as suas notações e transcriçõos musicais. Escolhemos, sim, os escritos que de algum modo tangenciam uma teoria crítica da linguagem musical no espaço do corpo da cultura brasileira - as observações do etnomusicólogo e etnólogo em sua caderneta de campo, material que ele utilizou com frequência em seus textos literários.

Mário reconhece a importância da música folclórica e popular como um saber que se diferencia organicamente da concepção erudita, principalmente em países colonizados. Sua compreensão do que ele chama de evolução da música no Brasil passa pelo pre- 
- (ANDRADE, Mário de. Aspectos da música brasileira. São Paulo: Martins, 1975: 21.)

(Ibidem: 23.)

(Ibidem: 24.) domínio de três grandes campos temáticos: "Deus" (a religiosidade musical imposta pela tradição católica nos primeiros séculos); o "amor" (a profanização, simbolizada pela modinha de salão e pelo melodrama romântico, a partir da Independência e durante todo o Império); e a "nacionalidade" (embrionária na Primeira República e já consistente no período da $1^{a}$ Guerra Mundial). (v. Aspectos da música brasileira: 1975)

Sobre a presença da religiosidade nas primeiras manifestações musicais no Brasil Colônia, ele afirma:

E por isso a música, ou mais exatamente, o canto místico dos jesuítas, funcionava também como elemento de religião, isto é, de religação, de força ligadora, unanimizadora, defensiva e protetora dos diversos indivíduos sociais que se ajuntavam sem lei nem rei no ambiente imediatamente post-cabralino: chefes nobres profanos, aventureiros voluntários, criminosos deportados, padres e selvagens escravos.

Mário observa que lentamente a música religiosa separava-se da liturgia católica, representando muito mais um elemento de socialização, de autoproteção, de identidade dos membros de distintas comunidades. Embora continuasse religiosa, essa música transformava-se em "enfeite nas festas de religião". Com o advento da escravidão, marcava-se cada vez mais uma distinção entre classes sociais, o que fez com que a música religiosa abandonasse a sua sustentação básica (as camadas populares), buscando acompanhar o imaginário da emergente elite escravocrata e latifundiária. De acordo com Mário:

Agora esta música religiosa não é mais víscera, é epiderme. Não é mais baixa, é elevada. Não é mais popular, mas erudita e nobre. Não é mais feia como a vida, mas pretende ser bela como a arte. É sim ainda europeia por ser católica, mas não é mais concomitantemente nacional. Não se utiliza de cateretês, porém apenas de uma solfas importadas, e de última moda rococó, em que vêm uns sons, uns instrumentos, uns ritmos, umas melodias, uns textos exclusivamente europeus, no mais dominador e insensível esquecimento da terra e do primeiro brasileiro que já nasceu. ${ }^{*}$

A Independência e a transformação da ex-colônia em Império possuem na música profana de inspiração sentimental a sua referência mais completa. "Nossa Ars Nova", como assim a definiu ironicamente Mário, formada pela expansão da modinha de salão de herança portuguesa e pela presença cada vez maior do melodrama oriundo do canto lírico, guardava uma relação direta com o ideário estético da poesia romântica. Segundo ele: 
É realmente no melodrama que está concentrada a manifestação musical erudita do Império. O país que se dava o luxo de distrair verbas graves para sustento e herança duma casa imperial, se dava também o luxo de sustentar a mais rica e brilhante estação de ópera da América de então. E foi a segunda fase histórica da nossa música, e resultado da sua evolução técnica. $\mathrm{O}$ corista-solista da polifonia religiosa colonial, dominando no superius do quarteto, e culminando no sopranista importado, cantador de árias de ópera até durante a realização do ofício divino, teve como consequência natural o cantor de teatro.

O terceiro e último momento corresponde ao deslocamento da música de "inspiração internacionalista", reduplicadora de formas e conteúdos da música europeia, característica da emergente República, para o espaço da inquietação e valorização do "estado de consciência musical nacionalista", presente na década de 10 , e que marcaria definitivamente a busca de um tom brasileiro como afirmação de nacionalidade. Destaca-se que Mário consegue confluir a sua compreensão do processo de transformação musical no Brasil para o mesmo solo de onde partiram as primeiras manifestações do modernismo. A análise da música (e da literatura, como podemos observar em Aspectos da literatura brasileira) marchava lado a lado com a avant-garde da utopia modernista, amalgamando em um só discurso a análise e o sonho, a vontade de entendimento e o desejo de transformação, Villa-Lobos e Oswald. Mário conclui:

Se de primeiro foi universal, dissolvida em religião; se foi internacionalista um tempo com a descoberta da profanidade, o desenvolvimento da técnica e a riqueza agrícola; se está agora na fase nacionalista pela aquisição de uma consciência de si mesma: ela terá que se elevar ainda um dia à fase que chamarei de Cultural, livremente estética, e sempre se entendendo que não pode haver cultura que não reflita as realidades profundas da terra em que se realiza. E então a nossa música será, não mais nacionalista, mas simplesmente nacional, no sentido em que são nacionais um gigante como Monteverdi e um molusco como Leocavallo.*

-(Ibidem: 34.)

A "música original brasileira", preocupação maior de seu pensamento, realinha o substrato do período colonial (a música como expressão de "religação" do homem com sua "origem"), atravessa a influência que o sentimentalismo de expressão romântica nos legou e chega, com sua plenitude criativa e poder de elaboração, ao momento histórico de afirmação da nacionalidade: o modernismo. Não se pode esquecer que a semana de 22 realizou-se propositalmente cem anos depois da Independência, comemorando por inversão análoga a pretendida autonomia e a autenticidade conquistada. 
Villa-Lobos passa a ocupar o lugar de referência dessa música que possui fundação na técnica, no formalismo e na tradição erudita europeia, mas que abre incisivamente seu campo auditivo e seu gesto político para as manifestaçôes populares. Essa é uma das razões das viagens que Mário fez pelo interior do país, pesquisando festas, danças, literatura oral e concepções musicais e folclóricas.

Segundo a sua convicção, a música folclórica, localizada $a$ priori nas zonas rurais, apresenta-se como a forma autóctone mais criativa, respaldada na "tradição necessária" e pilar de construção da "verdadeira identidade nacional". Percebe-se que em seu projeto nacionalista, a busca das origens, da singularidade e da pureza de princípios e expressão constitui a base principal. Congadas e maracatus são vistos como verdadeiras expressões da "alma popular", símbolos, dentre outros, de uma "cultura original e enraizada na tradição". Constata-se que a noção de "autenticidade" empregada é hoje fartamente discutível e fortemente equivocada.

Se, em um primeiro momento, a música folclórica rural guarda em si própria a condição de original, a música popular urbana, para Mário, caracteriza-se pela contaminação de internacionalismos, provocada pelo seu caráter de instabilidade, pela ausência de uma "tradição necessária".

O ensaísta Luiz Fernando Medeiros de Carvalho, estudando as composições do sambista Ismael Silva (Ismael Silva: samba e resistência), nos fornece um panorama bastante fértil das ideias de Mário a respeito da música popular urbana.

Sua análise sobre Ismael situa-se no contexto das transformações impostas pelo acelerado processo de urbanização na década de 20 e sua importância na passagem do Brasil do campo para o país de perfil cada vez mais moldado pela cidade. Carvalho constata que o impacto das mudanças afeta decisivamente a produção musical popular. O samba carioca deixa de transitar somente em seus ambientes tradicionais (os morros, a Pequena África e seus redutos) e passa a ocupar um espaço cada vez maior, devido principalmente à sua comercialização pela ainda incipiente indústria fonográfica e pelo advento da radiodifusão. $\mathrm{O}$ rádio utiliza a música como sua principal mercadoria, em particular o samba, abrindo ao compositor e cantor negros a possibilidade de profissionalização.

Carvalho constata a intransigência inicial de Mário quanto ao valor do samba comercializado, destituído, segundo ele, do "caráter autóctone". O ensaísta aponta a presença de estereótipos ligados à 
dicotomia originalidade/banalidade, à noção de autenticidade e de origem no pensamento de Mário, concepções que imobilizam uma leitura mais apurada das transformações pelas quais o samba carioca passou. Em um trecho de Música, doce música, Mário afirma:

Felizmente, no ar mais alto dos morros, o samba continuava a batucar, ignorado, firmando-se com mais liberdade e pureza na fraternidade das macumbas e dos cordōes de carnaval. E quando se sentiu púbere, já impossibilitado de sofrer novas deformaçôes essenciais, desceu para a cidade, e o Brasil o adotou. E vai resistindo galhardamente, a tudo, às rajadas instrumentais do $j a z z$, como à líquida emoliência das rumbas, ao chamalote internacional dos cassinos, como à canhestra incompetência burguesa. É por excelência, a nossa dança popular urbana.

Mário estabelece uma clara distinção entre "popular" e "popularesco". Segundo seus critérios, "popular" é a música de "caráter autóctone", que mantém os laços com a "tradição necessária", oriunda do período colonial; "popularesco" é o popular falseado, simulado, contaminado pelos "internacionalismos" e fator de diluição da criatividade popular. "Popularesco" é o produto da instabilidade da música urbana, de acordo com a sua avaliação.

Carvalho utiliza não só as ideias de Mário como também as do antropólogo Darcy Ribeiro para sustentar a tese de que o samba continua sendo uma manifestação popular significativa, produto de uma "cultura da pobreza" enriquecida pela capacidade de mobilização dos seus agentes produtores, apesar da absorção pela indústria cultural. Nesta direção, ele constata que a busca de Mário dos índices originais da nacionalidade, as "ilhas de arcaísmo", como Darcy Ribeiro compreende "os traços residuais das formas cristalizadas do período colonial” em oposição às manifestações contaminadas pela sua instabilidade, desemboca numa situação nova, a relativização imposta pelo musicólogo de sua leitura do samba. Carvalho aponta a existência no discurso de Mário da tensa relação entre procura da "pureza primitiva" e constatação da "perda da inocência”, projeção utópica de um desejo e retrato de um país se transformando. Nas suas próprias palavras:

Neste ponto deixa de apenas valorar as ilhas de arcaísmo e passa a considerar o samba sob novo prisma, diferente do critério de tradicionalização. Com a aceitação de que o samba guarda um valor folclórico (identificação com a sensibilidade popular), Mário escapa do centramento dos critérios de autenticidade. E não poderia ser diferente para o intelectual que operou uma trajetória em direção à 
(CARVALHO, Luiz Fernando Medeiros de. Ismael Silva: samba e resistência. Rio de Janeiro: José Olympio, 1980: 34.)

- (ANDRADE, Mário de. Música doce música. op. cit.: 280.) sensibilidade popular, que, por isso mesmo, impediu sua consciência de se alienar.

Buscando ler o samba fora do círculo da tradição, atribuindo-lhe valor folclórico pela sua identificação com o imaginário dos segmentos sociais cosmopolitas, Mário rascunha a planta baixa do que podemos denominar canção urbana moderna. Em Música, doce música, ele afirma:

$\mathrm{O}$ verdadeiro samba que desce dos morros cariocas, como o verdadeiro maracatu que ainda se conserva entre certas naçōes do Recife, esses, mesmo quando não sejam propriamente lindíssimos, guardam sempre, a meu ver, um valor folclórico incontestável. Mesmo quando não sejam tradicionais e apesar de serem urbanos.

O etnomusicólogo, entre aguerrido e melancólico, observa a sua face apocalíptica no espelho que a devolve como imagem integrada e redefinida. A demanda do muiraquitã que levou Macunaíma ao terreiro de Tia Ciata, ao encontro da cultura popular urbana, disseminada e descentralizada geograficamente como postulava o modernismo, leva Mário ao riquíssimo diálogo com a música brasileira, que vivia seu momento de transformação e fixação como gênero.

A "contaminação pela instabilidade", característica da música urbana, segundo o pensador paulista, acelerava-se com o advento da indústria fonográfica e da radiodifusão, como já constatamos. Sua percepção do uso da música como objeto comercializado (disco), reproduzido repetitivamente (rádio), leva-o a considerar a canção própria das cidades como mercadoria exposta no balcão dos supérfluos, destituída de suas "raízes" populares e transformada em banalidade popularesca. Mário acusa, entre polêmico e nostálgico, a perda de aura da música, do samba tradicional. Suas ideias tangenciam de alguma maneira os conceitos elaborados pelo filósofo Walter Benjamim em seu precioso ensaio $A$ obra de arte na era de sua reprodutibilidade técnica, publicado em 1936.

Benjamin adverte no início de seu texto que os fenômenos ali observados e analisados ainda estavam em sua fase inicial (o ensaio foi escrito entre 1935 e 36), por isso, mais do que certezas, ele apontava suposiçōes.

O tema central prende-se à análise das condições e efeitos que a reprodução técnica moderna produz sobre as obras de arte. O pensador alemão destaca que o conceito de reprodução do objeto ar- 
tístico sempre existiu, mas que a partir da litografia no século passado, da fotografia e do cinema no século XX, as suas implicações necessitavam de redefinições. Essas novas técnicas modificavam o conceito de reprodução e indicavam a falência do que Benjamin denomina a "aura" da obra de arte. Se a arte nasceu, como ele constata, dos impulsos ritualísticos da magia e da religião, os seus produtos, pelo estado rudimentar da reprodução, tornaram-se objetos únicos, detentores da autenticidade, possuidores de uma "alma distante" que iluminava a sua forma original. Com as possibilidades abertas pelas técnicas modernas, a reprodução da obra de arte redimensiona a discussão de seu papel como produto cultural e de sua recepção pelas sociedades contemporâneas. Benjamin afirma:

Em suma, o que é aura? É uma figura singular, composta de elementos espaciais e temporais: a aparição única de uma coisa distante, por mais perto que ela esteja. Observar, em repouso, numa tarde de verão, uma cadeia de montanhas no horizonte, ou um galho, que projeta sua sombra sobre nós, significa respirar a aura dessas montanhas, desse galho. Graças a essa definição, é fácil identificar os fatores sociais específicos que condicionam o declínio atual da aura. Ele deriva de duas circunstâncias, estreitamente ligadas à crescente difusão e intensidade dos movimentos de massas. Fazer as coisas ficarem mais próximas é uma preocupação tão apaixonada das massas modernas como sua tendência a superar o caráter único de todos os fatos através de sua reprodutibilidade. Cada dia fica mais irresistível a necessidade de possuir o objeto, de tão perto quanto possível, na imagem, ou antes, na sua cópia, na sua reprodução.

Benjamin constata que as modernas técnicas de reprodução das obras de arte destroem o espírito aurático do objeto e aniquilam os elementos que tradicionalmente representam a constituição da herança cultural. A necessidade que as massas modernas possuíam de ter a obra mais próxima, de dominar a sua concretude, mesmo que em segundo grau, copiada e simuladamente recomposta, destrói o sentido de objeto original, constituindo um novo modelo, uma nova forma de se relacionar com a arte, enfim, alterando substancialmente o conjunto produção/recepção da arte na sociedade capitalista. Benjamin deixa claro que o estético jamais seria percebido da mesma maneira, que a reprodução técnica havia transformado definitivamente a arte em mercadoria produzida em série.

Mas o pensador alemão também acreditava que o abalo proporcionado por tal fenômeno produziria outro quadro relacional entre as massas e a arte, transfigurando-as em agentes transforma-
- (BENJAMIN, Walter. "A obra de arte na era de sua reprodutibilidade técnica". In: Obras escolhidas I-Magia e técnica, arte e política. São Paulo: Brasiliense, 1993: 170.) 
dores da sociedade, politizando, ao lado dos próprios artistas, a produção estética.

Sua leitura da nova situação destoa em parte da visão radical de outros pensadores da Escola de Frankfurt, especialmente Adorno. Benjamin considerava a possibilidade de surgimento de outro relacionamento entre as massas e a arte, que instrumentalizasse com eficácia a mudança das estruturas de criação cultural. Sua perspectiva não é a da opção pela arte autocentrada, isolada dos não iniciados, verdadeira prática de uma "arte pela arte" que privilegia os segmentos elitizados da sociedade, em particular a figura do intelectual moldado pela ratio iluminista, e despreza os graus de recepção das camadas proletárias. Benjamin parte das condiçôes e dos elementos existentes, mesmo sabendo que são adversos e fortemente comprometidos, tentando fazer com que as massas ditas alienadas levem a efeito uma nova atitude diante da produção cultural, mais consciente e engajada.

Em princípio, as ideias de Mário de Andrade sobre a utilização pelo capitalismo do objeto artístico como mercadoria, de sua constante desreferencialização e perda de substância histórica, estão em parte mais próximas do pensamento de Adorno, crítico do que ele mesmo denominou "postura otimista" de Benjamin diante da catástrofe que representava a massificação da indústria cultural.

A cena da macumba na casa de Tia Ciata, um dos capítulos de Macunaíma que será discutido logo a seguir, guardaria, segundo Mário, em seus rituais de magia e religiosidade a ainda intocável aura da música autêntica dos negros, forma original preservada nos seus espaços fundadores - o morro, a Pequena África, seus redutos específicos. Sua força viria de seu "valor autóctone", do respeito à "tradição necessária", de sua "percepção popular": objeto único, autêntico, puro, envolvido pela aura retro-iluminadora de sua condição histórica. Mas o disco e o rádio destruíram, segundo o mesmo Mário, a pureza e a inocência do samba, massificando a sua audição e contaminando a sua essência de manifestação cultural original.

Em 1928, Mário de Andrade produziu dois de seus mais importantes textos - Macunaíma, por ele denominado rapsódia (e a escolha do gênero musical é bastante significativa), e o Ensaio sobre a música brasileira. Inúmeras são as possibilidades de diálogo e aproximação dos dois textos, apesar de pertencerem a gêneros distintos - romance e ensaio. 
Mário defende em seu Ensaio a recriação do "populário" como um dos ideais modernistas, ou seja, o desenvolvimento dos elementos da cultura popular não contaminados pelo processo civilizatório. O "cultivo do populário", na acepção alemã de Build, é uma questão fundamental para a compreensão de suas ideias acerca da relação cultura erudita/cultura popular, nacional/estrangeiro. Para ele, popular deveria ser reconhecido e valorizado, mas submetido a um processo de elaboração e transformação a partir de uma tradição erudita. Segundo a leitura da antropóloga Santuza Naves:

Mário propõe nesse ensaio que se promovam pesquisas históricas e etnográficas, visando recolher peças do repertório musical - folclóricas ou de autoria conhecida - que revelariam, pela constância de características comuns, a inteireza da alma brasileira. Lidando com a categoria "música artística", isto é, produzida por um artista "interessado", comprometido com a problemática nacional, Mário prescreve o que fazer com os elementos pesquisados, que deveriam ser utilizados como ingredientes básicos para a criação de composiçôes elaboradas no âmbito da experiência erudita.

Pode-se reconhecer a presença de boa parte das ideias defendidas no Ensaio na concepção e construção de Macunaíma. No capítulo "Macumba", uma das inúmeras variações da rapsódia, o narrador descreve a ida do herói a um ritual afro-brasileiro no Mangue, zona portuária do Rio de Janeiro, símbolo da marginalidade, prostituição e malandragem nas primeiras décadas do século passado. Buscando vingar-se do gigante Venceslau Pietro Pietra, Macunaíma vai ao reduto do samba carioca, a velha cidade, no terreiro de Tia Ciata, pedir a Exu diabo que desse uma lição no inimigo.

Era junho e o tempo estava inteiramente frio. A macumba se rezava lá no Mangue no zungu da tia Ciata, feiticeira como não tinha outra, mãe-de-santo famanada e cantadeira ao violão. Às vinte horas Macunaíma chegou na biboca levando debaixo do braço o garrafão de pinga obrigatório. Já tinha muita gente lá, gente direita, gente pobre, advogados garçons pedreiros meias-colheres deputados gatunos, todas essas gentes e a função ia principiando. Macunaíma tirou os sapatos e as meias como os outros e enfiou no pescoço a milonga feita de cera de vespa tatucaba e raiz seca de assacu. Entrou na sala cheia e afastando a mosquitada foi de quatro saudar a candomblezeira imóvel sentada na tripeça, não falando um isto. Tia Ciata era uma negra velha com um século no sofrimento, javevó e galguincha com a cabeleira branca esparramada feito luz em torno da cabeça pequetita. Ninguém mais não enxergava olhos nela, era só ossos duma compridez já sonolenta pendependendo pro chão de terra.
- (NAVES, Santuza Cambraia. Da bossa nova à tropicália. Rio de Janeiro: Jorge Zahar Editor, 2001: 60.)

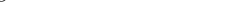

-(ANDRADE, Mário de. Macunaíma. Rio de Janeiro: Livros Técnicos e Científicos; São Paulo: Secretaria da Cultura, Ciência e Tecnologia, 1978: 55.) 
' (MOURA, Roberto. Tia Ciata e a Pequena África no Rio de Janeiro. Rio de Janeiro: Funarte /INM /Divisão de música popular, 1983: 57.)
Tia Ciata, "mãe-de-santo famanada e cantadeira ao violão", era a mais famosa das baianas que migraram para o Rio depois da abolição da escravatura e durante a passagem da Monarquia para a República. Hilária Batista de Almeida (Tia Ciata, Siata, Aciata ou Assiata) tornou-se famosa em sua época pelos seus pratos típicos de origem africana, comida de orixás, seus doces, pela sua liderança nas linhas místicas do candomblé e por ter sido uma das primeiras a dar corpo aos ritmos ancestrais, ao canto e à dança oriundos da África e sincretizados no Brasil sob a denominação genérica de samba. Como nos afirma o pesquisador Roberto Moura:

A colônia baiana se imporia no mundo carioca em torno de seus líderes vindos dos postos do candomblé e dos grupos festeiros, se constituindo num dos únicos grupos populares no Rio de Janeiro com tradições comuns e coesão, cuja influência se estenderia a toda a comunidade heterogênea que se forma nos bairros em torno do cais do porto, e depois na Cidade Nova, tocados pelas transformações urbanas. A modernização da cidade e a situação de transição nacional fazem com que indivíduos de diversas experiências sociais, raças e culturas se encontrem nas filas da estiva ou nos corredores das cabeças-de-porco, promovendo já no fim da República Velha a formação de uma verdadeira cultura popular carioca definida por uma densa experiência sócio-cultural que, embora subalternizada e quase que omitida pelos meios de informação da época, se mostraria, juntamente com os novos hábitos civilizatórios das elites, fundamental na redefinição do Rio de Janeiro e na formação de sua personalidade moderna.

O ponto de encontro dos desterrados (baianos negros que vieram para o Rio; ex-escravos que não faziam parte do sonho modernizador; trabalhadores braçais e desempregados; prostitutas; pobres; pretos; poetas populares), o ponto de encontro dos desterrados era a Pequena África - da praça Onze ao Estácio, do porto ao longo do canal do Mangue, coração estrangeiro expulso pela ocidentalização de um progresso imposto pelas elites da capital da República.

A casa de Tia Ciata transformou-se em referência da história não oficial do Rio. Comia-se, bebia-se, rezava-se, dançava-se, cantava-se longe do ouvido afinado dos salóes. Formava-se o espaço da dissonância de uma cultura deserdada e excluída. A parte de trás do terreno abrigava um gênero musical e coreográfico que, por ser proibido como manifestação pública pela polícia, só podia se apresentar longe da calçada, da rua, da sala de estar - no "fundo de quintal". O samba urbano carioca vivia sob inspeção permanente e controle das forças policiais. Seus movimentos maxixados eram 
considerados obscenos, seu ritmo interpretado como manifestação primitiva e suas letras carentes do que se considerava, segundo os cânones vigentes, verdadeira poesia. $\mathrm{O}$ corpo erótico contrapunha-se ao corpo repressor e reprimido, representado basicamente pela burguesia ascendente e pela Igreja. Cabe-nos observar que não só o samba do Rio, mas também o de roda do recôncavo baiano e o rural de São Paulo foram perseguidos. Sobre essa relação cultura popular/controle ideológico/repressão do Estado, Mário afirmava num trabalho de campo no interior paulista:

Também nesta parada em Pirapora, apesar duma colheita muito mais frutuosa e completada, não fui muito feliz. A festança estava fraca, este ano e aquele dia e em vez dos pelo menos três grupos de samba que esperava encontrar, um só reinava. A principal razão da fraqueza derivou da reação dos padres e excesso de repressão policial contra a parte profana dos festejos. [...] Este ano os barracões, por determinação dos padres, de mãos dadas com a Polícia, só serviam de dormida, sendo proibido sambar neles. Os sambas foram expulsos pro ar livre (aliás seu lugar tradicional), e para as entradas da cidade.

As entradas de Pirapora e as ruelas da Pequena África atestam os limites impostos às manifestações populares. No caso do Rio, especificamente, o crescente redesenho da cidade expurgava de suas áreas nobres e privilegiadas o proletariado e os segmentos sociais à margem da cidadania consentida. Contingentes cada vez maiores de sua população transferiam-se, por força da imposição transformadora e da industrialização acelerada, para os morros e a periferia ou dividiam as novas fronteiras urbanas com a elite, tensão presente até os dias atuais. Criou-se uma verdadeira cultura de resistência que teve no samba um de seus símbolos mais radicais.

Dois romances emblemáticos da literatura do século XIX, Memórias de um sargento de milícias de Manuel Antônio de Almeida e O cortiço de Aluísio Azevedo, buscam, cada um a seu modo, problematizar com menor ou maior ironia, as tensas relaçôes que marcam a formação da sociedade brasileira. Em ambos, o lugar central que as manifestaçóes da cultura popular ocupam, em particular a música, é uma poderosa chave de entendimento da construção de certa identidade nacional simbolizada na figura do malandro, um músico, quase sambista.

Macunaíma está diante de Tia Ciata, "uma negra velha com um século de sofrimento" e alguns outros de história. O narrador em outro momento do texto descreve o início da cerimônia:
- (ANDRADE, Mário de. Aspectos da música brasileira. op. cit.: 147. ) 
"(ANDRADE, Mário de. Macunaíma. op. cit.: 56 .)
Então a macumba principiou de deveras se fazendo um sairê para saudar os santos. E era assim: Na ponta vinha o ogã tocador de atabaque, um negrão filho de Ogum, bexiguento e fadista de profissão, se chamando Olelê Rui Barbosa. Tabaque mexemexia acertado num ritmo que manejou toda a procissão. E as velas jogaram nas paredes de papel com florzinhas, sombras tremendo vagarentas feito assombração. Atrás do ogã vinha tia Ciata quase sem mexer, só beiços puxando a reza monótona. E então seguiam advogados taifeiros curandeiros poetas o herói, gatunos, portugas, senadores, todas essas gentes dançando e cantando a resposta da reza.

A sociedade brasileira está em boa parte ali representada. Seus segmentos, suas divisões de classe, advogados e gatunos, taifeiros e senadores, suas etnias, origens, seus impasses e dilemas. De uma ponta vinha "o ogã tocador de atabaque, um negrão filho de Ogum, bexiguento e fadista de profissão", descrição de Alfredo da Rocha Viana Filho, o Pixinguinha.

Ao lado de Donga, João da Baiana e Sinhô, dentre vários, Pixinguinha representa o início de uma aristocracia do samba cario$\mathrm{ca}$, acrescida mais tarde de compositores como Geraldo Pereira, Ismael Silva, Cartola, Nélson Cavaquinho, Paulinho da Viola, Martinho da Vila e Zeca Pagodinho. A exceção é Noel Rosa, compositor branco de classe média que fez do samba a linguagem de apreensão de outro universo do Rio de Janeiro, construção estética tão ao gosto contemporâneo de Aldir Blanc e, principalmente, Chico Buarque de Hollanda. Frequentador das casas das baianas, das tias - Perpétua, Veridiana, Mônica, Gracinda e, principalmente, Ciata - Pixinguinha foi um dos responsáveis pela afirmação e expansão da música popular como linguagem de inserção sociocultural.

Sabe-se que foi por volta de 1926 que Mário de Andrade procurou o músico em São Paulo em busca de informações e material que pudessem auxiliá-lo em um "livrinho" que estava escrevendo. O encontro ocorreu intermediado pelo amigo em comum Antônio Bento, outro colaborador de Mário. Reunindo dados e cuidadosamente anotando o que o flautista lhe dizia, Mário iniciava $M a-$ cumba, sétima variação de seu "livrinho"/rapsódia. Sobre essa passagem, os pesquisadores Marília Barbosa da Silva e Arthur de Oliveira Filho no livro Filho de Ogum Bexiguento afirmam:

Mário projetava descrever uma cena de macumba que sintetizasse as características de tal cerimônia em várias partes do território nacional: uma macumba desgeografizada, segundo o próprio autor, incluindo em seu transcurso elementos de candomblés baianos e das 
pajelanças paraenses. Pixinguinha fora íntimo da famosa tia Ciata, baiana cuja casa era conhecida no Rio de Janeiro, tanto pelas festas (na sua casa nasceu o primeiro samba Pelo Telefone), como pelas famosas sessões onde se cultuavam os orixás africanos. Ele narrou a Mário tudo quanto teria assistido, trocou-lhe em miúdos diversas práticas fetichistas. Mário recolheu as informaçōes, fundiu-as às dos outros colaboradores e, da colagem, nasceu a descrição do afamado candomblé da tia Ciata, onde a negra velha cantava o nome dos santos que tinham de saudar e o coro secundava: Va-mo-sa-ra-vá!.*

Ao lado de Pixinguinha, bem próximas a Macunaíma, vozes de curandeiros, poetas, portugas cantam e corpos de advogados, gatunos, senadores dançam. A casa de Ciata transforma-se no palco onde os dramas pessoais e sociais se sucedem. Onde, conduzido pela magia da magia e pela magia da música, o Brasil das contradições, das diferenças se mostrava. Ao lado de uma visão da música como celebração da igualdade entre os homens, percebe-se a sua utilização como força apaziguadora das contradições, suspendendo aparentemente diferenças raciais, culturais e socioeconômicas. A música que não é só pulsão que desrecalca, mas também força que sublima o sofrimento humano.

No trecho final de Macumba o narrador observa:

E pra acabar todos fizeram a festa juntos comendo bom presunto e dançando um samba de arromba em que todas essas gentes se alegraram com muitas pândegas liberdosas. Então tudo acabou se fazendo a vida real. E os macumbeiros, Macunaíma, Jaime Ovalle, Dodô, Manu Bandeira, Blaise Cendrars, Ascenso Ferreira, Raul Bopp, Antônio Bento, todos esses macumbeiros saíram na madrugada.

Personagens ficcionais e personagens históricos encontram-se num final frenético de celebração da comida, da dança e da música. Tia Ciata, Macunaíma, Pixinguinha, os macumbeiros, os poetas Ovalle, Bandeira, Cendrars, Ferreira, Bopp, os amigos Dodô e Bento entoam uma verdadeira ópera carnavalizada, mostrando em sua última cena "esses macumbeiros" modernistas saindo na madrugada em direção à vida.

Mário de Andrade apaga e confunde com sutileza os tênues limites entre a ficção e a história. Não constrói uma narrativa histórica nem se dedica exclusivamente à concretude inter-muros do discurso do imaginário. Mistura num melting pot antropofágico personagens-cidadãos e cidadãos-personagens, Bahia, Rio e Europa, músicos, poetas, escritores, senadores, taifeiros e gatunos anônimos, e se torna autor de si mesmo - Macunaíma incorpora Má-
- (SILVA, Marília B. da e OLIVEIRA FILHO, Arthur de. Filho de Ogum bexiguento. Rio de Janeiro: Funarte, 1979: 85.)

- (ANDRADE, Mário de. Macunaíma. op. cit.: 63.) 
rio, Macunaíma é o seu cavalo simbólico que pela madrugada passeia pelo Mangue, pela Pequena África, pelo Brasil, pelas comidas, crenças, danças e músicas entre múltiplas vozes.

Sua ficção é a da criação para além do real histórico e para dentro do real ficcional - "então tudo acabou se fazendo a vida real". Percebe-se com clareza a importância que a cultura popular possui no seu pensamento e no jogo narrativo proposto. Para o etnólogo, as lendas, os mitos, os causos, o artesanato e a musicalidade são componentes importantes na interlocução com a cultura erudita, suas referências e atributos. Macunaíma é hoje um cult, clássico do modernismo brasileiro. Sua realização formal, sua arquitetura narrativa e seus timbres discursivos são um exemplo definitivo do alto narrar. Mas são de composições como a variação Macumba, que põem em tensão o alto e o baixo narrares, que a rapsódia e toda a obra de Mário são compostas. Comparando a variação Macumba com a nona, Carta pras Icamiabas, nota-se como o seu texto alterna modulações, propõe distintos registros linguísticos, busca espaço para uma das propostas mais musicalmente literárias de Mário de Andrade - a polifonia.

Em Macunaima, e em particular no capítulo que tivemos a oportunidade de comentar, Mário exercita com alegórica violência a vontade etnográfica, a construção de um discurso que ficcionalmente pretende ser uma das maneiras de se ler, com incontrolável e contraditória paixão, a cultura brasileira.

\section{Júlio Diniz}

É Professor Associado, Diretor do Departamento de Letras da PUC-Rio e Pesquisador do CNPq.

Palavras-chave: música; literatura; Mário de Andrade; Macunaíma; poética.

\section{Resumo}

O texto tem como objetivo principal analisar e discutir a contribuição crítica do pensamento de Mário de Andrade sobre a relação música, cultura e literatura, em especial a poesia. A produção intelectual de Mário caracteriza-se por uma busca incessante de compreensão do sentido da arte, da cultura e do Brasil através da constituição do que poderia ser denominado um pensamento polifônico. Os estudos e ensaios sobre música, ao lado de uma profunda inquietação antropológica e etnográfica, deixam marcas definitivas em sua atividade ficcional, como pode ser observado na leitura de um capítulo de Macunaíma. 


\section{Abstract}

The text analyzes and discusses Mário de Andrade's critical contribution to the relation between music, culture and literature, particularly poetry. Andrade's intellectual production is characterized by a constant search for an understanding of the meaning of art, culture and Brazil, through the creation of what might be called a polyphonic view. His studies and essays on music, together with his keen interest in anthropology and ethnography, left deep marks in his fiction, as a reading of a chapter from Macunaíma shows clearly.

\section{Résumé}

Ce texte a pour objectif principal d'analyser et de discuter la contribution critique de la pensée de Mario de Andrade sur la relation entre la musique, la culture et la littérature, en particulier la poésie. La production intellectuelle de Mario de Andrade se caractérise par une recherche incessante de la compréhension du sens de l'art, de la culture et du Brésil à travers la constitution de ce que l'on pourrait nommer une pensée polyphonique. Ses études et ses essais sur la musique, à côté d'une profonde inquiétude anthropologique et ethnographique, laissent des marques définitives dans son activité fictionnelle, comme l'on peut remarquer par la lecture d'un seul chapitre de Macunaíma.
Key words: music; literature; Mário de Andrade; Macunaíma; poetics.

Mots-clés: musique; littérature; Mário de Andrade; Macunaíma; poétique. 